(

I<smiles>CC1=CC=C2CC(O)CCC2(C)C1</smiles>

IX<smiles>CC1CCC2=CC(=O)CCCC2(C)C1C</smiles>

$\mathrm{x}$<smiles>CC1CCCC2CC(O)CCCC2(C)C1C</smiles>

XI<smiles>CC1CCC23CC(C)C(=O)C=C2CC(O)CCC3(C)C1</smiles>

III<smiles>CC1C=CC2=CC(=O)CCC2(C)C1</smiles>

V<smiles>CC1CC(O)C2=CC(O)CCC2(C)C1C</smiles>

VII

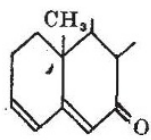

IV<smiles>CC1CC(O)C2(O)CC(O)CCC2(C)C1C</smiles>

VI<smiles>CC1CC(=O)C2CC(O)CCC2(C)C1C</smiles>

VIII it is to be hoped that the saturated sterols so frequently stated to be present in tissues will be reinvestigated, especially with regard to their complete chemical identification, since it certainly cannot be stated with confidence that coprosterol itself is absent from the body cells.

Since the above substances (II-VIII) are such as may arise in normal cells during life, it would appear reasonable that they should be tested for physiological activity, especially of the kind which may be directly associated with growth processes.

1 Bergström, S., and Wintersteiner, O., J. Biol. Chem., 141, 597 (1941); 143, 503 (1942); 145, 309, 327 (1942).

${ }^{2}$ Haslewood, G. A. D., Biochem. J., 33, 709 (1939).

3 MacPhillamy, H. B., J. Amer. Chem. Soc., 62, 3518 (1940).

4 Wintersteiner, O., and Ritzmann, J. R., J. Biol. Chem., 138, 697 (1940).

s Prelog, V., Ruzicka, L., and Stein, P., Helv. chim. Acta, 26, 2222 (1943). - Hardegger, E., Ruzicka, L., and Tagmann, E., Helv. Chim. Acta,
26, 2205 (1943).

'Ruzicka, L., and Prelog, V., Helv. Chim. Acta, 26, 975 (1943).

'Haslewood, G. A. D., Biochem. J., 35, 708 (1941).

- Windaus, A., Bursian, K., and Riemann, U., Z. physiol. Chem., 271, 177 (1941).

${ }^{10}$ Bloch, K., and Rittenberg, D., J. Biol. Chem., 145, 625 (1942); 149, 505, 511 (1943).

${ }^{11}$ Rosenheim, O., and Webster, T. A., Biochem. J., 37, 513 (1943).

1s Rosenheim, O., and Webster, T. A., Biochem. J., 37, 580 (1943).

${ }^{23}$ Rosenheim, O., and Webster, T. A., Biochem. J., 35, 920 (1941).

\section{OBJECTIVE CLINICAL METHODS}

A. NEW and remarkably ingenious example of the A objective clinical methods which are constantly being developed in modern medicine and surgery is the phono-electrocardioscope designed by Dr. G. E. Donovan (The Lancet, 500, April 15, 1944), which permits simultaneous direct visual recording of the phonocardiogram, electrocardiogram and sphygmogram, with amplified auscultation through a binaural stethoscope; in addition, photographic records can be made. The expense of such instruments and the difficulty of producing them in sufficient numbers will prevent all but a few workers from using them, but it is worth remembering that some of them can be applied to the study of the normal animal as well as to the sick animal for whose relief they were invented. The electrocardiograph and the techniques of radiography, cystoscopy and duodenal intubation are examples of objective clinical techniques which can be, and are being, used by anatomists and biologists for studies which have no connexion with disease. The cystoscope or the ophthalmoseope, for example, need not always be used for the study of the bladder or the eye. The principle on which such instruments are constructed can be applied to other things. If an instrument allow's you to look into the bladder of a man, it may be used also for seeking out the death watch beetle underneath a floor, and it is being used in this way by Prof. Bayley Butler in Dublin; and the biologist, the medical man and the veterinarian can all use modern methods of studying the fluids and soft tissues of the body and so demonstrate that they are all students in the same field of inquiry.

There will always be, however, an especially close correlation between the methods of the medical man and the veterinarian, because it is their common object to understand and to treat disease - or better, to prevent its occurrence and to maintain health. The trend of medical thought is, or should be, as Prof. J. A. Ryle and other medical men have pointed out (see Nature, 153, 443; 1944), to teach medical students to rely less upon instruments and laboratory procedures and more upon the art of clinical observation and inference in which their grandfathers were so skilled. There will, however, always be some aspects of disease which require the instrument and the laboratory expert. You may be able to diagnose malaria or amœbic dysentery with adequate accuracy by experienced interpretation of the symptoms only, but a protozoologist can do it much more quickly and with absolute certainty ; in certain cases, indeed, his laboratory report may be the only means of doing it or of saving the patient's life. In the same way, radiography or the electrocardiograph may give vital information which could not be got in any other way.

The value of such objective methods of study can perhaps be most clearly demonstrated when they are applied to patients who cannot tell the medical man or the veterinarian. what their sufferings are. The deaf and dumb adult, the infant and the young child who cannot speak-or, if he can, cannot make reliable statements about himself-must tax to the full the art of the clinician who has only his own experience to guide him. Very often such patients require the aid of objective studies by means of instruments or laboratory procedures which eannot, so the optimist at any rate believes, tell a lie. The neurotic or hysterical adult may also require this 
kind of study ; and there are some diseases, such as trichiniasis, which are so protean in their manifestations and simulate so many other diseases that the diagnosis can only be made by the finding of the parasite or by serological methods which depend upon considerable laboratory experience. The veterinarian, of course, is always confronted by this kind of difficulty; his patients may be able to utter cries the quality of which may tell the experienced hearer of the vital things, but they cannot tell the whole story, and the experience necessary to interpret them comes only after years of practice. It comes, moreover, only to those who have the ability to acquire it; and it cannot be communicated to students and others except by a similar long experience based on a similar ability.

In a matter like this, the veterinarian and the medical man must therefore find a wide field of mutual interest. It is a field which deserves energetic co-operation and exploration. If the children's doctor may seem to be most likely to profit from such co-operation, the whole of medicine may learn much from the study of animal illness. Comparative medicine, whether it be practised by the medical man or the veterinarian, must certainly have a direct interest in objective methods of study which can give it reliable information about the conditions of certain organs, or about such cardinal symptoms as the quality, intensity and distribution of pain, about normal and pathological variations in body temperature, about fatigue, the reactions of the autonomic nervous system and so on. Much might be learnt, too, from a comparative study of the reactions to certain cardinal symptoms of disease which are shown by animals so different as the carnivore, the ungulate, the mammal and the bird.

The interpretation of the results of studies such as these will not be easy. They will usually involve behaviour patterns for the study of which the cooperation of a psychologist will be required. Perhaps we could begin with a reconsideration of the whole basis of Pavlov's work, or at least with a critical examination of certain criticisms of it (see. British Medical Journal, 487, Oct. 16, 1943; ibid., 305, Aug. 14, 1943; and ibid., 573, April 22, 1944), which would seem to merit the serious attention of biologists. At any rate, we should have to begin with carefully thought out basic experiments, planned by a medical man, a veterinarian and a psychologist, which would be designed to provide a basis for further work. Such a plan has, in fact, been farmulated by the Institute of Animal Behaviour, a committee of which is designing a programme of work the object of which is to explore the possibility of creating an objective science of clinical study. A similar theme was discussed at a recent meeting of the Section of Comparative Medicine of the Royal Society of Medicine. There exists, of course, a great deal of knowledge based on objective experiment which will help such a project; and both the medical man and the veterinarian can supply a vast store of clinical experience which will, if it can be systematized, be invaluable. Meanwhile the explorers stand upon their peak in Darien. Let us wish success to their campaign on behalf of all those, whether they be human or animal, who suffer but cannot tell their sufferings, or, if they would tell, are prevented by their own constitutions or immaturities from telling the truth or directing attention to the root causes of their troubles.

\section{THE IMPERIAL CANCER RESEARCH FUND}

$T$ HE Imperial Cancer Research Fund, which has just issued its forty-first annual report, is still carrying out experimental work and is also improving its financial position. During the past year, more than $£ 20,000$ has been added to the capital account, so that the Fund has now almost $£ 430,000$ in hand and spends about $£ 15,000$ a year in supporting research work in its laboratories at Mill Hill.

With a scientific staff of seven and four visiting workers, the laboratories are working in many fields of cancer research. The visitors include Sir John Ledingham, Dr. L. Dmochowski from Poland and Dr. E. Vasquez-Lopez from Madrid. The report of the director, Dr. W. E. Gye, is divided into sections on carcinogenesis, tissue culture, the mammary tumour inciter, and chemotherapy.

The work on carcinogenesis consists of Mr. H. G. Crabtree's study of the effects on the induction of cancer in mice of substances which inhibit metabolic processes. He has found that organic halogen compounds which react with substances containing sulphur in the body are able to retard the induction of tumours on the skin of mice painted with a carcinogen. The halogen compounds are of two types: those in which the halogen is reactive, as in chloroacetone, and combines directly with sulphydryl groups, and others, such as bromobenzene, which react with sulphur compounds in the body without loss of halogen. Both types of compound appear to cause a local fall in concentration of glutathione when applied to the skin of mice. A similar effect was looked for with maleic anhydride, as it is known that maleic acid combines with glutathione. Maleic anhydride applied to the skin of mice treated with benzpyrene proved to be a more potent inhibitor of carcinogenesis than is bromobenzene. The work suggests that sulphur compounds are connected with the induction of tumours in some way which is not yet clear.

If connective tissue cells are grown in tissue culture in contact with carcinoma cells, the growth of the former is stimulated. On the other hand, sarcoma cells tend to restrain the growth of connective tissue. Stimulating effects of carcinomata have long been known to operate in vivo, as the change of connective tissue cells into malignant cells in the presence of transplanted mammary tumours has often been observed. Dr. R. J. Ludford and Miss H. Barlow have tried to demonstrate such a malignant transformation in connective tissue cells grown in vitro in contact with mammary cancer tissue, but so far without success.

The effect of the mammary tumour inciter, discovered in the Roscoe B. Jackson Memorial Laboratory in the United States, which is present in the milk of strains of mice with a high incidence of breast cancer, has now been shown to operate in the high-cancer strain $R I I I$ and the low-cancer strain $S$. It is pointed out that the fact that oestrone treatment induces tumours in male mice of susceptible strains indicates that the factor is present in the tissues as well as in the milk of mice in which mammary cancer occurs. The presence of the inciter in spleen tissue has been confirmed.

The difficulties of work on chemotherapy of cancer are discussed. For effective therapy either all the cancer cells must be destroyed, or the stimulus to divide which is present in these cells must be neutral- 